DOI: 10.22616/REEP.2020.017

\title{
Development of Transversal Competences in Case Study-based Professional English Course in Business Administration Studies
}

\author{
Tatjana Sinkus Dr.paed. \\ Latvia University of Life Sciences and Technologies, Latvia \\ tshinkus@yahoo.com
}

\begin{abstract}
Transversal competences are fundamental in the 21 st century and necessary for every higher educational institution graduate as they are prerequisites for well-being and success in life, adapting to the changeable and complex world and meeting multiple demands of today's society, being competitive in the labour market, managing profitable business and developing an enterprise. The aim of the study was to describe the process of developing such transversal competences as critical thinking, collaboration and creativity in case study-based professional English course in business administration studies. The results were obtained in a pedagogical experiment involving business administration students in case study modules within the professional English course. The students developed transversal competences during a case study-based course and the article presents ways of how practical acquisition of critical thinking, collaboration and creativity competences was achieved.
\end{abstract}

Keywords: university education, professional English, transversal competences, case study.

\section{Introduction}

The research in the 21 st century competences is commonly associated with the increased significance of so called "transversal competences" as they are considered by theorists as crucial indicators for employability, meeting complex demands and competitiveness. Nowadays it is widely accepted that transversal competences should be developed in the higher educational institution (Lima et al., 2017; Ananiadou, Claro, 2009; Gordon et al., 2009; Birjandi, Bagherkazemi, 2010; Bröckling, 2006; Robinson, 2011; Jackson, 2013; Hildebrand, 2008).

Transversal competences provide an opportunity of effective participation and self-realization in a variety of educational, professional, social and personal life contexts. They are multifunctional and span numerous aspects of human life comprising knowledge of various academic disciplines. There is no unified conceptual framework describing transversal competences, every scientist and each initiative introduces complementary ideas to this concept. Though, a large number of studies highlights the importance of developing such transversal competences as critical thinking, collaboration and creativity.

The students of business administration studying professional English require a course which not only provides opportunities to develop foreign language skills but would also help them think independently, rationally, creatively and teach them how to work in teams sharing responsibility for accomplishing a common task. Moreover, teaching English in the higher educational institution the educator should take into account specific features of students' future profession.

The article suggests that the case study method helps the teacher to adapt foreign language teaching process to the needs of future specialists. Case study modules in the professional English course are directed to student cognitive skills' development, they increase motivation, provide active, problem-based, communicative learning, which leads to transversal competences' development. Thus, the aim of the study was to describe the process of developing such transversal competences as critical thinking, collaboration and creativity in case study-based professional English course in business administration studies.

\section{Theoretical background}

\section{Critical Thinking}

Critical thinking is an important life skill for people today (Mimbs, 2005). Students must be trained critical thinking skills to be able to think critically for their future career (Badri-Gargari, Fathi-Azar, 2007). Students can be transformed in their learning through continued and consistent use and application of critical thinking skills (Adeyemi, 2012). 
Canada research (Shifting Minds..., 2012, 10) suggests that thinking critically requires students to "acquire, process, interpret, rationalize, and critically analyze large volumes of often conflicting information to the point of making an informed decision and taking action in a timely fashion. The knowledge and digital era is demanding people with higher order thinking skills; the ability to think logically, and to solve ill-defined problems by identifying and describing the problem, critically analyzing the information available or creating the knowledge required, framing and testing various hypotheses, formulating creative solutions, and taking action".

Critical thinking is the "ability to design and manage projects, solve problems, and make effective decisions using a variety of tools and resources" (Fullan, 2013, 23). It "applies to all sorts of knowledge and implies the true engagement of learners in the process of knowledge construction through reflecting and thinking deeply; curiosity and questioning are necessary characteristics of those who think critically as they always try to find answers for the questions they raise." (Saleh, 2019, 2).

It should be noted that critical thinking is a complex notion and it is difficult to integrate all its components into a common single definition. In many ways, these definitions are similar, repeated in the literature and complementary. However, there are some obvious common elements regarding critical thinking that can be summarized as following:

- an ability to raise vital questions and problems, formulating them clearly and precisely,

- an ability to identify the relevance and importance of ideas,

- an ability to understand the logical connections between ideas,

- an ability to analyze complex issues and situations,

- an ability to gather, compare and assesses relevant information, evaluate arguments,

- an ability to draw conclusions based on reliable information,

- an ability to detect mistakes in reasoning,

- an ability to solve problems systematically,

- an ability to synthesize and make connections between subjects,

- an ability to communicate effectively with others in figuring out solutions to problems,

- an ability to transfer insights to new contexts.

Critical thinking is an essential competence required for success in the 21 st century, it is of great importance in modern life, and it should be taught to students, especially adult learners at the higher educational institution. Most traditional lecturers tend to present facts to the students who are passively supposed to acquire these bits of theoretical knowledge. However, educators supporting critical thinking have a different approach and try to involve students in active learning providing situations in which the students can discuss arguments, express their opinion and analyze information.

\section{Collaboration}

Since most jobs nowadays require individuals to work in teams where each team member contributes to a finished product or completed service, collaboration is a vital competence that every person should develop in the 21 st century. Collaboration enables an individual "to work effectively as a member of a team in order to achieve a common benefit; being active, helpful and bringing a personal contribution to the teamwork; gaining new knowledge from other participants and transferring it to new situations, compromising and resolving conflicts." (Sinkus, 2019a, 178)

Collaboration involves groups working together to solve a problem, complete a task, or create a product, learning from others, listening to different perspectives, presenting opinions and defending them. Working collaboratively, individuals do not solely rely on an expert's opinion but develop their own unique skills and abilities and apply them in diverse situations, roles, groups, in order to construct knowledge and meaning. New skills and knowledge are necessary to enable group members to collaborate in digital age, facing each other or working remotely. As C. Dede $(2010,2)$ states: "In addition to collaborating face-to-face with colleagues across a conference table, 21 st century workers increasingly accomplish tasks through mediated interactions with peers halfway across the world whom they may never meet face-to-face. Thus, even though perennial in nature, collaboration is worthy of inclusion as a 21 st century skill because the importance of cooperative interpersonal capabilities is higher and the skills involved are more sophisticated than in the prior industrial era". 
In the context of foreign language learning, collaboration is frequently associated with communicative language learning approach as opposed to traditional teacher-oriented studying from books. According to J. Richards and T. Rodgers (Richards, Rodgers, 2001, 193) "collaborative language learning seeks to build naturalistic, elaborate, and motivating language learning environments that, using interactive activities, help learners in taking advantage of different ways of learning and communication".

T. Sinkus $(2019 b, 171)$ suggests using the case study method in the professional English course as it can provide students with a wide range of opportunities for valuable collaborative and communicative language practice. The author investigated students' opinion on the case study method's usage in the professional English course and the study showed that the majority of the students considered case studies as an opportunity "to experience and enjoy more creative and engaging way of learning, helped build confidence in speaking English and find new objectives in learning the foreign language. Most students appreciated the opportunity to approach business problems from various perspectives, develop foreign language interactive skills, apply what they learned in practice, reflect on participation in case study, and increased responsibility for learning".

In order to achieve better results in collaborative problem solving students should develop social skills, flexibility and empathy, an ability to compromise, work respectfully with others to make decisions taking into account the needs of the whole group and considering the views of all group members, an ability to accept different roles, and share responsibility for the created common product.

\section{Creativity}

According to I. Bojāre and S. Ignatjeva (Bojāre, Ignatjeva, 2014, 43), "nowadays, a paradigm shift leads to facilitation learners to become creative. Such creativity and autonomy is precondition not only of sustainable long term learning during one's life, but also for openness and meeting challenges of changes, creating new knowledge and acquisition unpredictable skills in the future".

In the 21 st century creativity has become crucial for economic growth, social development, competition in business. The need for creative problem-solving ideas has arisen as more and more modern issues require creative insights, generating novel ideas, looking at things from a different perspective and freedom of restrictions by rules and norms in order to find suitable solutions.

The Partnership for $21^{\text {st }}$ Century Skills framework (P21 Framework Definitions, 2009, 5) underlines the importance of thinking creatively, working creatively with others and implementing innovations. According to this framework, creativity involves "the ability to turn ideas into action to meet the needs of a community. The capacity to enhance concepts, ideas, or products to contribute new-to-the-world solutions to complex economic, social, and environmental problems involves leadership, taking risks, independent/unconventional thinking and experimenting with new strategies, techniques, or perspectives, through inquiry research".

U. Bröckling $(2006,513)$ points out to a great necessity of creativity development in 21 st century. The researcher states that "The importance of being creative is nowadays connected to the mobilisation of the entrepreneurial self. Entrepreneurial action demands permanent innovation and consequently ceaseless creative exertion. Everybody not only has to be simply creative, but more creative than the others".

N.J. Jackson (2013) views creativity as a versatile term including such characteristics as being imaginative, possessing ability to think generatively, being original, inventive, curious, resourceful, being able to think synthetically and to connect ideas/things in unusual ways, being able to think critically to evaluate ideas, being able to communicate in ways that help people comprehend and being able to see things differently. The theorist presents strategies that higher education teachers should use to facilitate students' creativity. They can be summarized as following:

- giving students permission to be creative, encouraging and valuing creativity,

- providing time and safe spaces for students where they can try new things out,

- developing students' self-confidence in dealing with unpredictable situations,

- promoting the development of self-awareness and reflective learning,

- providing activities that are meaningful to learners,

- providing opportunities to develop autonomy and independence, personal choice, 
- providing students with challenging real-world situations where there are no right answers,

- demonstrating their own creativity and providing a role model,

- acting as guides and facilitators, being responsive to students as a group and as individuals,

- being prepared to take risks and reveal something of themselves in the teaching process,

- creating opportunities for problem or enquiry-based approaches to learning, for collaborative working, discussion, negotiation and experience-rich learning,

- focusing on learning for understanding not content mastery.

Thus, in order to develop student abilities to think creatively educators should make higher education more experiential and linked to the world of real problem solving. A 21st century competent individual should 'think outside the box', sometimes risking, looking at things from different angles, being unique and original.

\section{Methodology}

One hundred and seven 1st year students of Baltic International Academy studying in business administration programme during three consecutive study years, six groups of students: 2015-2016 study year - 37 students (2 groups), 2016-2017 study year - 48 students (2 groups), 2017-2018 study year -22 students ( 2 groups) took part in the experiment: they were involved in case study modules within the professional English course with the aim to develop such transversal competences as critical thinking, collaboration and creativity.

The professional English course was divided into three modules titled Negotiations, Meetings and Presentations where the students were assigned a case, which they studied individually, discussed in pairs and small groups, studied vocabulary and professional terminology, were involved in various activities related to a case: discussions, roleplays, simulations; then they were assessed, reflected on their work and the work of their peers, and presented their self-evaluation. Following is the description of the ways of how the author of the article approached transversal competences' development by involving the students of business administration in case study modules in the professional English course.

\section{Results and Discussion}

\section{Critical thinking competence development in case study modules}

To foster critical thinking in the context of business problems, the author used case study modules comprising cases and case-based activities (role-plays, simulations, discussions and presentations) from business settings. The students were exposed to business problems that helped them relate the material learned in business administration studies to the foreign language learning.

The students were actively involved in cases that were based on a business situation as decision makers and were asked to examine the problem from a variety of perspectives, to reason their way to a solution and to arrive at conclusions. All the cases involved a question or problem that was not evident or obvious to the students who had to take up the role of decision makers. In all the cases, more than one answer was possible and the students could suggest any solution of the problem they wanted on the purpose that their ideas were supported with credible arguments, sources, knowledge and information.

The case study process enabled the teacher to emphasize business administration subject matter and focus on both the foreign language knowledge development and critical thinking enhancement within a reality-based context. The author used realistic problem-based scenarios of cases to lead students to understand business administration concepts deeper and apply foreign language communication into the analysis of business situations.

Case study modules provided the students with the opportunity to enhance critical thinking through such case study phases as individual work, group work and the whole class activities where they acquired new knowledge and applied it in discussion and analysis of a case/problem. In different phases of the case, students developed critical thinking competence through involvement in high order thinking processes. Critical thinking levels involved knowledge and comprehension, application, analysis and evaluation, synthesis, creation and reflection. The summarized and listed in Table 1 below procedures 
describe how the case study phases involved the students in application of critical thinking competence's components development on various levels.

The students were also engaged in common whole class result creation based on the synthesis of all information and knowledge derived from several small groups, as well as in reflection about their work. All these processes lead to critical thinking competence development.

Table 1

Critical thinking competence development

\begin{tabular}{|c|c|c|}
\hline $\begin{array}{c}\text { Case } \\
\text { study } \\
\text { phases }\end{array}$ & $\begin{array}{c}\text { Critical } \\
\text { thinking } \\
\text { levels }\end{array}$ & Procedures of critical thinking competence application in case study \\
\hline 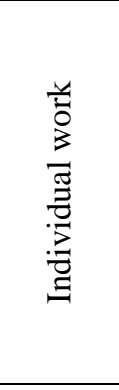 & 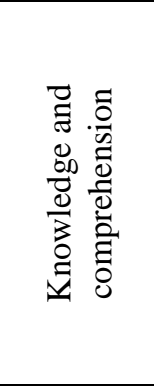 & $\begin{array}{l}\text { - reading the case scenario and defining the central problem of the case; } \\
\text { - identifying underlying facts and assumptions; } \\
\text { - learning new vocabulary and expressions; } \\
\text { - gathering relevant information, knowledge and formulating questions; } \\
\text { - identifying business concepts involved in the case; } \\
\text { - breaking down the case into constituent parts; } \\
\text { - filling in the missing information; } \\
\text { - retelling case information into one's own words; } \\
\text { - problem situation comprehension; }\end{array}$ \\
\hline 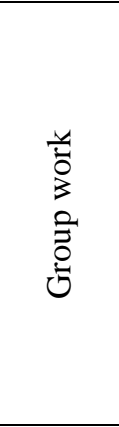 & 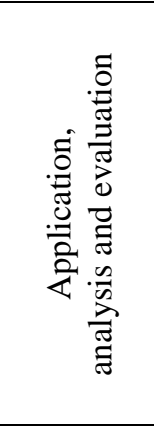 & $\begin{array}{l}\text { - discussing/analyzing the problem with other students in small groups; } \\
\text { - questioning, interpreting and explaining the problem; } \\
\text { - differentiating similarities and differences in opinions on the case; } \\
\text { - establishing criteria to evaluate alternate solutions and evaluating information from } \\
\text { multiple perspectives; } \\
\text { - assessing the validity and relevance of information, knowledge, sources; } \\
\text { - criticizing perspectives and assumptions; } \\
\text { - defending arguments, using evidence to support arguments; } \\
\text { - assessing strength and weaknesses of options; } \\
\text { - drawing conclusions; }\end{array}$ \\
\hline 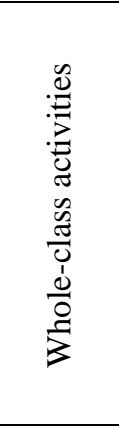 & 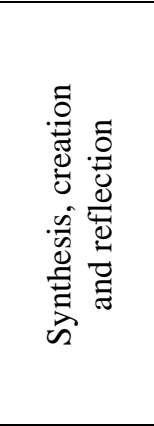 & $\begin{array}{l}\text { - developing strategies or action plan; } \\
\text { - linking data, knowledge, and insight together from various disciplines; } \\
\text { - presenting the results of the case obtained in small groups and discussing the case } \\
\text { as a whole-class activity; } \\
\text { - putting the results of all small groups together to form a common result; } \\
\text { - constructing new knowledge or perspectives; } \\
\text { - engagement in self-reflection; } \\
\text { - engagement in self- and peer assessment; } \\
\text { - applying decisions and conclusions; } \\
\text { - transferring newly acquired knowledge into new situations. }\end{array}$ \\
\hline
\end{tabular}

\section{Collaboration competence development in case study modules}

The necessity of collaboration in the case study arose from the fact the tasks were too complex and rigorous to complete individually. Working on a case involved students in active interaction and collaboration with others to achieve a common goal - to learn together and to solve a problem.

Collaborative learning involved small groups of students mutually searching for understanding, solutions or meanings through discussions. The students participated in small group work and in whole class discussion, exchanged ideas and shared responsibilities. They were required to work actively as a member of a team bringing personal contribution.

The teacher formed small groups of 4-5 people to avoid student non-participation. By assessing students both individually and as a group the teacher ensured individual accountability of the group members. Also, the students had to evaluate their own participation as well as that of their peers. Assigning meaningful roles such as a manager, a monitor or a leader for each case-based task gave students ownership of the case study process and allowed the teacher to assess students based on accomplishing of these roles. 
Before beginning group work, the teacher explained the students the principles of collaboration: what makes a good team member versus what makes a difficult one, as well as strategies for working with others, sharing the load responsibly, and overcoming disagreements. Teaching collaboration explicitly, the teacher provided the students with opportunities for its practice, and provided continuous feedback to ensure further development and progress of collaboration competence. Collaboration competence development process is summarised in Figure 1 below.

\begin{tabular}{|c|c|}
\hline Collaboration competence indicators & Case study modules' activities promoting collaboration \\
\hline $\begin{array}{l}\text { - gaining new knowledge from other } \\
\text { participants, exchange of views and } \\
\text { experience with other team members; }\end{array}$ & $\begin{array}{l}\text { - discussion of case introductory questions in small groups and } \\
\text { sharing with experience in negotiating, taking part meetings } \\
\text { and giving presentations; } \\
\text { - defining business concepts and terms' in small groups; } \\
\text { - brainstorming about the secrets of success in negotiations, } \\
\text { meetings and presentations; }\end{array}$ \\
\hline $\begin{array}{l}\text { - working toward a team's common } \\
\text { mutual goal; defending opinions; } \\
\text { - clarifying understanding; } \\
\text { - } \quad \text { ability to negotiate; } \\
\text { - } \quad \text { synthesizing information; }\end{array}$ & $\begin{array}{l}\text { - discussion in small groups about the rules on how to prepare } \\
\text { to negotiate, to take part in a meeting and give a presentation; } \\
\text { - drawing up a list of rules (students write questions to ask } \\
\text { themselves to prepare thoroughly), compare the results with } \\
\text { other groups; }\end{array}$ \\
\hline $\begin{array}{l}\text { - } \text { reliability and accountability; } \\
\text { - being active and helpful, bringing } \\
\text { personal contribution to the group work; }\end{array}$ & $\begin{array}{l}\text { - in small groups, students study the case dividing the task of each } \\
\text { member of the group, conducting an individual study, share with } \\
\text { the findings obtained, offer a solution to the problem; } \\
\text { - all group members comment, agree or disagree with it, } \\
\text { synthesize all information and negotiate the final result; }\end{array}$ \\
\hline $\begin{array}{l}\text { - being able to resolve conflicts; } \\
\text { - nurturing positive relationships; } \\
\text { - supporting others to achieve a common } \\
\text { goal, understanding mutual dependence; }\end{array}$ & $\begin{array}{l}\text { - students read their instructional cards and act out a role-play } \\
\text { with different goals (negotiating pay rise, a discount, a day } \\
\text { off) using new vocabulary; } \\
\text { - students use polite phrases, listen patiently, seek a mutually } \\
\text { acceptable agreement and find a compromise; }\end{array}$ \\
\hline $\begin{array}{l}\text { encouraging team members to contribute } \\
\text { their perspectives, skills or knowledge. }\end{array}$ & $\begin{array}{l}\text { - students assess their small group work and the work of peers, } \\
\text { giving positive feedback, criticizing, encouraging to work } \\
\text { actively. }\end{array}$ \\
\hline
\end{tabular}

Figure 1. Collaboration competence development.

\section{Creativity competence development in case study modules}

Case study modules presented the students with a wide range of opportunities and freedom to express their unique creative identity. The teacher assigned cases where there was no single possible answer and the students were encouraged to think differently, use their imagination and resourcefulness and come up with original ideas for the purpose of solving problems.

Various methods and activities aimed to develop student creative thinking were used in the professional English language course. The students participated in brainstorming and brainwriting, acting out situations, roleplays, simulations, delivering presentations, creating advertisements and videos, answering open-ended questions, predicting, etc. In order to demonstrate their presentations, videos and advertisements the students used visuals, technology and multimedia.

The students used the foreign language in a creative way in communication during the lessons. Interactivity was an important element of case study modules which stimulated the student ability to be flexible, use creative and imaginative ways of expression. To use new language constructions, vocabulary and expressions, the students had to overcome language problems in order to make the message intelligible and to adjust their language to different situations and purposes.

The students also used various strategies to make up for the lack of language in communicative situations, for example, using humour, miming, paraphrasing, giving examples to get meaning across. The learners had to combine ideas, materials and resources in an original way to create a common product and present their group's unique way to solve the problem. Creativity competence development process in the professional English course is depicted in Figure 2 below. 


\begin{tabular}{|c|c|}
\hline Creativity competence indicators & Case study modules' activities promoting creativity \\
\hline $\begin{array}{l}\text { - seeking new unobvious perspectives and } \\
\text { opportunities in business environment; } \\
\text { - solving problems in an innovative, non- } \\
\text { traditional, original way; } \\
\text { - combining materials or resources in order to } \\
\text { create something new; }\end{array}$ & $\begin{array}{l}\text { - brainstorming and brainwriting ways how to solve a } \\
\text { case; } \\
\text { - predicting the outcome of the case; } \\
\text { - discussion: how to stay ahead of competitors; } \\
\text { - discussing factors of a successful presentation, } \\
\text { meeting, negotiations; } \\
\text { - presenting multiple solutions of the case; }\end{array}$ \\
\hline $\begin{array}{l}\text { - experimenting with new ideas and roles; } \\
\text { - being flexible in communication with different } \\
\text { people in various circumstances; }\end{array}$ & $\begin{array}{l}\text { - acting out new situations, trying out new roles in } \\
\text { roleplays, simulations; } \\
\text { - using new language; }\end{array}$ \\
\hline $\begin{array}{l}\text { coming up with original ideas to improve } \\
\text { business procedures; }\end{array}$ & $\begin{array}{l}\text { - answering open-ended questions about the case: } \\
\text { What if...? Is there a better way....? How could you } \\
\text { improve...? }\end{array}$ \\
\hline $\begin{array}{l}\text { - exploring multiple perspectives; } \\
\text { - ability to create new ideas in collaboration; } \\
\text { - evaluating and adjusting ideas or innovations to } \\
\text { suit the goal of the case study; }\end{array}$ & - interacting in groups on the case; \\
\hline $\begin{array}{l}\text { combining ideas, materials and resources in an } \\
\text { original way to create a common product; } \\
\text { the ability to adjust the foreign language to } \\
\text { different purposes, addressees, and situations; } \\
\text { presenting ideas and demonstrating the } \\
\text { confidence to implement innovative ideas; }\end{array}$ & $\begin{array}{l}\text { - presentation of the results of the group case study to } \\
\text { the whole class; }\end{array}$ \\
\hline $\begin{array}{l}\text { - demonstrating initiative, resourcefulness when } \\
\text { transforming ideas into products or services; } \\
\text { - search for competitiveness opportunities; } \\
\text { - using imagination, experimenting; } \\
\text { - using humour. }\end{array}$ & $\begin{array}{l}\text { - creating an innovative product/service and giving } \\
\text { a presentation about it; } \\
\text { creating an advertisement to stay ahead of } \\
\text { competitors and keep up with latest trends; } \\
\text { - video creation: 'successful presentation of the } \\
\text { product', followed up by a discussion on what are } \\
\text { the effective strategies of the presentation. }\end{array}$ \\
\hline
\end{tabular}

Figure 2. Creativity competence development.

\section{Conclusions}

To sum up, transversal competences such as critical thinking, collaboration and creativity are regarded as very significant for each higher educational institution graduate in the 21 st century regardless of the program they study. The benefits of developing each competence for the students of business administration, prospective entrepreneurs, cannot be underestimated as well. Critical thinking competence enables an entrepreneur to think rationally, logically, systematically, analyse issues and make independent judgement. Collaboration competence enables an entrepreneur to work effectively as a member of a team in order to achieve a business benefit; being active, helpful and bringing a personal contribution to the teamwork compromising and resolving conflicts. Creativity competence enables an entrepreneur to seek new unobvious perspectives and opportunities in business environment, come up with original ideas to improve business procedures, solve problems in an innovative, non-traditional way, keep up with the latest business trends and stay ahead of competitors.

Development of critical thinking, collaboration and creativity was incorporated into the professional English course using the case study modules which presented a wide range of opportunities to develop transversal competences. During the pedagogical expreriment the students were actively involved in cases based on a business situation as critical decision makers, they actively participated in interaction and collaboration with others to achieve a common goal - to learn together and to solve a problem coming up with original ideas to improve business procedures and expressing their unique creative identity. 


\section{Bibliography}

1. Adeyemi S.D. (2012). Developing Critical Thinking Skills: A Mandate for Higher Education in Nigeria. European Journal of Educational Research, 1(2), 155-161. Retrieved from https://files.eric.ed.gov/fulltext/EJ1086348.pdf

2. Ananiadou K., Claro M. (2009). 21st Century Skills and Competences for New Millennium Learners in OECD Countries. OECD Education Working Papers, 41, OECD Publishing: Paris. doi: 10.1787/218525261154

3. Badri-Gargari R., Fathi-Azar S. (2007). A Comparison of the Effect of the Group Problem Based Learning and Traditional Teaching on Critical Thinking of Teacher Students. Studies in Educational and Psychology, 8(2) 16, 27-42.

4. Birjandi P., Bagherkazemi M. (2010). The Relationship Between Iranian EFL Teachers' Critical Thinking Ability and Their Professional Success. English Language Teaching, 3(2),135-145. Retrieved from https://pdfs.semanticscholar.org/ff71/d780a75b8a3c2e526a68d3f2b82437c38c39.pdf

5. Bojāre I., Ignatjeva S. (2014). Autonomous English Acquisition in Blended e-studies for Adults for Sustainable Development: Quantitative research. In V. Dislere (Ed.), The Proceedings of the International Scientific Conference Rural Environment. Education. Personality (REEP), 7. Jelgava: LLU, 42-49. Retrieved from https://lufb.llu.lv/conference/REEP/2014/Latvia-Univ-Agricult-REEP-2014proceedings-42-49.pdf

6. Bröckling U. (2006). On Creativity: A Brainstorming Session. Education Philosophy and Theory, 38(4), 513-521. doi: 10.1111/j.1469-5812.2006.00208.x

7. Dede C. (2010). Comparing Frameworks for 21st Century Skills. In J. Bellanca, R. Brandt (Eds.). $21^{s t}$ Century Skills: Rethinking How Students Learn. Bloomington, IN: Solution Tree Press; 2010: 51-75 Retrieved from http://citeseerx.ist.psu.edu/viewdoc/summary?doi=10.1.1.475.3846

8. Fullan M. (2013). The New Pedagogy: Students and Teachers as Learning Partners. Learning Landscapes, 6(2), 23-29. doi: 10.36510/learnland.v6i2.601

9. Gordon J., Halsz G., Krawczyk M., Leney T., Michel A., Pepper D., Putkiewicz E., Wisniewski J. (2009). Key Competences in Europe. Opening Doors for Lifelong Learners across the School Curriculum and Teacher Education. Warsaw: CASE Retrieved from http://www.caseresearch.eu/upload/publikacja_plik/27191519_CNR_87_final.pdf

10. Hildebrand D. (2008). The Powerful Benefits of Lifelong Learning. Winnetka, California, USA: Scientific Research an Academic Publisher.

11. Jackson N.J. (2013). Developing Students' Creativity through a Higher Education. Retrieved from https://www.researchgate.net/publication/321036375_Developing_Students'_Creativity_through_a_Highe r_Education

12. Lima R.M., Mesquita D., Rocha C., Rabelo M. (2017). Defining the Industrial and Engineering Management Professional Profile: A Longitudinal Study Based on Job Advertisements. Production, 27, 1-15. Retrieved from http://www.scielo.br/scielo.php?script=sci_arttext\&pid=S0103-65132017000200317

13. Mimbs C. (2005). Teaching from the Critical Thinking, Problem Based Curricular Approach: Strategies, Challenges, and Recommendations. Journal of Family and Consumer Sciences Education, 23(2), 7-12. http://w.natefacs.org/Pages/v23no2/v23no2Mimbs.pdf

14. P21 Framework Definitions. (2009). Partnership for $21 \mathrm{st}$ Century Skills. Retrieved from https://eric.ed.gov/?id=ED519462

15. Richards J., Rodgers T. (2001). Approaches and Methods in Language Teaching. New York: Cambridge University Press. Retrieved from https://www.novaconcursos.com.br/blog/pdf/richards-jack-c.-\&rodgers.pdf

16. Robinson K. (2011). Out of Our Minds: Learning to be Creative. Chichester, UK: Capstone Publishing. Retrieved from http://www.fredkemp.com/5365su12/robinsonchpt123.pdf

17. Saleh S.E. (2019). Critical Thinking as a 21st Century Skill: Conceptions, Implementation and Challenges in the EFL Classroom. European Journal of Foreign Language Teaching, 4(1), 1-15. doi: 10.5281/zenodo.2542838

18. Shifting Minds: A $21^{\text {st }}$ Century Vision of Public Education for Canada. (2012). Canada: C21 Canadians for $21^{\text {st }}$ Century: Learning and Innovation. Retrieved from http://www.c21canada.org/wpcontent/uploads/2012/05/C21-Canada-Shifting-Version-2.0.pdf

19. Sinkus T. (2019a). The Development of Professional English Language Competence in Business Administration Studies. In V. Dislere (Ed.), The Proceedings of the International Scientific Conference Rural Environment. Education. Personality (REEP), 12. Jelgava: Latvia University of Life Sciences and Technologies, 173-181. doi: 10.22616/REEP.2019.022

20. Sinkus T. (2019b). The Implementation of Transformative Case Study Model for the Development of Professional English Language Competence in Business Administration Studies. In V. Dislere (Ed.), The Proceedings of the International Scientific Conference Rural Environment. Education. Personality (REEP), 12. Jelgava: Latvia University of Life Sciences and Technologies, 165-172. doi: 10.22616/REEP.2019.021 